\title{
Pengaruh Kualitas Pelayanan, Pemahaman Peraturan dan Sanksi Perpajakan Pada Kepatuhan WPOP
}

\author{
I Made Yoga Widiana ${ }^{1}$ \\ Fakultas Ekonomi dan Bisnis \\ Universitas Udayana, Indonesia. \\ Email: yogawidiana97@gmail.com
}

\author{
I Ketut Jati ${ }^{2}$ \\ Fakultas Ekonomi dan Bisnis \\ Universitas Udayana, Indonesia.
}

\begin{abstract}
ABSTRAK
Salah satu cara untuk meningkatkan penerimaan pemerintah dari sektor pajak adalah dengan meningkatkan kepatuhan wajib pajak itu sendiri. Tujuan penelitian ini adalah untuk mengetahui pengaruh kualitas pelayanan, pemahaman peraturan dan sanksi perpajakan pada kepatuhan wajib pajak orang pribadi yang terdaftar di KPP Pratama Badung Utara. Penelitian dilakukan di KPP Pratama Badung Utara tahun 2018. Pemilihan sampel sebanyak 100 orang wajib pajak menggunakan rumus slovin. Pengumpulan data dilakukan dengan menyebarkan kuesioner kepada WPOP yang terdaftar di KPP Pratama Badung Utara dan teknik analisisnya menggunakan analisis regresi linier berganda. Berdasarkan hasil analisis, diketahui bahwa kualitas pelayanan, pemahaman peraturan dan sanksi perpajakan berpengaruh positif pada kepatuhan wajib pajak orang pribadi yang terdaftar di KPP Pratama Badung Utara, dengan nilai thitung masing-masing variabel lebih besar dari $t_{\text {tabel, }}$ serta memiliki nilai signifikansi lebih besar dari 0,05 .
\end{abstract}

Kata Kunci : Kualitas Pelayanan; Pemahaman Peraturan Perpajakan; Sanksi Perpajakan; Kepatuhan Wajib Pajak Orang Pribadi.

\section{Effect of Service Quality, Understanding of Tax Regulations and Sanctions on WPOP Compliance}

\section{ABSTRACT}

One way to increase government revenue from the tax sector is by increasing taxpayer compliance itself. The purpose of this study was to determine the effect of service quality, understanding of regulations and taxation sanctions on individual taxpayer compliance registered at North Badung KPP Pratama. The study was conducted at the KPP Badung Utara in 2018. The sample selection was 100 taxpayers using the Slovin formula. Data collection was carried out by distributing questionnaires to WPOP registered in North Badung KPP Pratama and the analysis techniques using multiple linear regression analysis. Based on the results of the analysis, it is known that service quality, understanding of regulations and taxation sanctions have a positive effect on individual taxpayer compliance registered in North Badung KPP Pratama, with the value of calculating each variable greater than the label, and having a significance value greater than 0.05 .

$\begin{array}{ll}\text { Keywords: } & \text { Quality of Service; Understanding Of Tax } \\ & \text { Regulations; Tax Sanctions; Individual Taxpayer } \\ & \text { Compliance. }\end{array}$

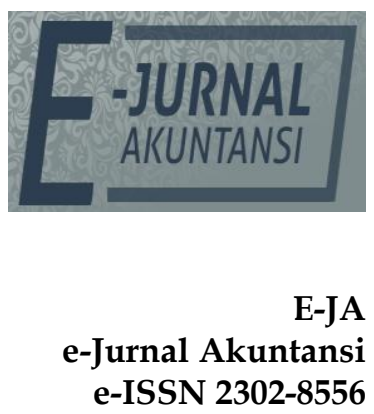

Vol. 29 No. 2

Denpasar, November

2019

Hal. 503-521

Artikel masuk:

16 Juli 2019

Tanggal diterima:

02 Agustus 2019 


\section{PENDAHULUAN}

Pajak merupakan iuran rakyat kepada kas Negara berdasarkan undang-undang (yang dapat di paksakan) dengan tidak mendapat jasa timbal balik (kontraprestasi) yang digunakan untuk kepentingan pemerintah dan untuk masyarakat umum, Mardiasmo (2011). Pajak sebagai salah satu sumber pendapatan negara digunakan sebagai sumber dana bagi pemerintah untuk membiayai pengeluaran-pengeluarannya, dan sebagai alat untuk mengatur atau melaksanakan kebijaksanaan pemerintah dalam bidang sosial dan ekonomi. Sektor pendapatan negara terbesar berasal dari sektor pajak, hal tersebut dapat dilihat pada Tabel 1 tentang realisasi penerimaan negara yang berasal dari pajak dan jumlah penerimaan negara yang bukan berasal dari pajakmenurut data dari Badan Pusat Statistik tahun 2018.

Tabel 1. Realisasi Penerimaan Negara Tahun 2014-2018. (Triliun Rupiah)

\begin{tabular}{cccc}
\hline Tahun & Penerimaan pajak & $\begin{array}{c}\text { Penerimaan bukan } \\
\text { pajak }\end{array}$ & Total \\
\hline 2014 & $1.146,9$ & 398,6 & $1.545,5$ \\
2015 & $1.240,4$ & 255,6 & 1496,0 \\
2016 & $1.285,0$ & 262,0 & $1.547,0$ \\
2017 & $1.472,7$ & 260,2 & 1732,9 \\
\hline
\end{tabular}

Sumber : Kemenkeu.Go.Id, 2018

Berdasarkan Tabel 1. menunjukan bahwa penerimaan dari sektor pajak lebih besar dibandingkan penerimaan dari sektor non pajak, hal tersebut membuktikan bahwa kontribusi pajak sangat signifikan dan terus meningkat dari tahun ketahun sebagai sumber penerimaan Negara.Pajak digunakan untuk membiayai rumah tangga negara yaitu pengeluaran-pengeluaran yang bermanfaat bagi masyarakat luas dan sebagai alat untuk mengatur atau melaksanakan kebijakan pemerintah dalam bidang ekonomi (Poulson and Kaplan, 2008). Terdapat dua fungsi pokok pajak (Mardiasmo, 2011:11) yaitu fungsi penerimaan (budgetair) adalah pajak sebagai sumber dana bagi pemerintah untuk membiayai pengeluaran-pengeluaran dan fungsi mengatur (regulerend) pajak sebagai alat untuk mengatur atau melaksanakan kebijakan pemerintah dibidang social dan ekonomi.

Pelaksanaan kewajiban perpajakan oleh wajib pajak dapat dituangkan dalam bentuk pengisian Surat Pemberitahuan (SPT) pada setiap akhir masa pajak dan melaporkannya ke Kantor Pelayanan Pajak (KPP) dalam masa batas waktu yang telah ditentukan. SPT dalam self assesment system merupakan sarana yang digunakan oleh wajib pajak untuk melakukan perhitungan atas pajak terutangnya, kemudian melaporkan dengan benar semua hal dari identitas wajib pajak, kegiatan usaha sampai harta yang semua berkaitan dengan perpajakan. Wajib pajak juga menggunakan SPT ini sebagai dasar atau bukti bahwa wajib pajak tersebut telah melakukan kewajiban perpajakannya (Handayani, 2013:2). Maka wajib pajak seharusnya memiliki pemahaman tentang tata cara pengisian SPT yang benar agar tidak terjadi kesalahan pada saat pengisian SPT.

Isu kepatuhan menjadi penting karena ketidakpatuhan secara bersamaan akan menimbulkan upaya untuk menghindari membayar pajak. Kepatuhan wajib pajak (tax compliance) dapat diidentifikasi dari kepatuhan wajib pajak dalam mendaftarkan diri, kepatuhan untuk menyetorkan kembali SPT, 
kepatuhan dalam penghitungan dan pembayaran pajak terutang. Kepatuhan wajib pajak perlu diperhatikan dan diawasi karena berkembangnya praktik penghindaran pajak (tax evasion) yang dapat menimbulkan kerugian pada negara (Fidel, 2010:139). Berikut adalah tingkat kepatuhan pelaporan surat pemberitahuan tahunan (SPT) wajib pajak orang pribadi dikantor pelayanan pajak pratama badung utara dapat dilihat dari Tabel 2. berikut.

Tabel 2. Rasio Kepatuhan Wajib Pajak Orang Pribadi (WPOP) di KPP Pratama Badung Utara Pada Tahun 2014-2017

\begin{tabular}{ccccc}
\hline No & Tahun Pajak & Jumlah WPOP & $\begin{array}{c}\text { SPT Tahunan Yang } \\
\text { Masuk }\end{array}$ & Kepatuhan (\%) \\
\hline 1 & 2014 & 54.581 & 26.302 & 48,18 \\
2 & 2015 & 58.527 & 26.200 & 44,76 \\
3 & 2016 & 62.035 & 27.075 & 43,64 \\
4 & 2017 & 65.712 & 27.568 & 41,95 \\
\hline
\end{tabular}

Sumber : KPP Pratama Badung Utara, 2018

Tingkat kepatuhan pelaporan SPT Tahunan wajib pajak orang pribadi di KPP Pratama Badung Utara berdasarkan tabel 2 pada Tahun 2014 sebesar 48,18 persen, kemudian pada Tahun 2015 menurun sebesar 44,76 persen, kemudian pada Tahun 2016 turun menjadi 43,64 persen, dan pada tahun 2017 turun sebesar 41,95 persen. Tingkat kepatuhan yang ditunjukkan oleh wajib pajak orang pribadi di KPP Pratama Badung Utara masih rendah. Hal ini dapat dilihat dari rata-rata tingkat kepatuhan wajib pajak orang pribadi dari tahun 2014-2017 sebesar 44,63 persen.

Tingkat kepatuhan wajib pajak dipengaruhi oleh beberapa faktor, salah satunya adalah kesadaran wajib pajak. Kesadaran wajib pajak merupakan kondisi dimana wajib pajak mengetahui, mematuhi, dan melaksanakan kewajiban perpajakan dengan benar dan sukarela (Noviantari and Setiawan, 2018). Hasil penelitian yang di lakukan oleh Torgler (2005) menyatakan bahwa salah satu masalah yang paling serius bagi para pembuat kebijakan ekonomi adalah mendorong tingkat kepatuhan wajib pajak. Hal tersebut didukung oleh Simanjuntak (2009) dalam penelitiannya dijelaskan bahwa, kepatuhan pajak (tax compliance) sebagai indikator peran masyarakat dalam memenuhi kewajiban perpajakan masih rendah. Kepatuhan pajak yang tidak meningkat akan mengancam upaya pemerintah untuk meningkatkan kesejahteraan masyarakat (Chau, 2009). Hal ini dikarenakan tingkat kepatuhan pajak secara tidak langsung mempengaruhi ketersediaan pendapatan untuk belanja (Jung, 1999).

Hasil penelitian Supadmi (2009) untuk meningkatkan kepatuhan wajib pajak dalam memenuhi kewajiban perpajakannya, kualitas pelayanan pajak harus ditingkatkan oleh aparat pajak. Kualitas pelayanan juga dinilai sebagai perbandingan antara harapan yang diinginkan oleh pelanggan dengan penilaian mereka terhadap kinerja aktual dari suatu penyediaan layanan (Cronin, 1992). Menurut Palda (2002) kemauan wajib pajak untuk membayar pajak sebagian besar dipengaruhioleh kualitas pelayananyang diberikan oleh pemerintah. Perasaan senang danpuas atas pelayanan yang diberikan oleh pemerintah dapat memicu motivasi dan kepatuhan bagi wajib pajak yang akhirnya dapat meningkatkan penerimaan negara. 
Kepatuhan wajib pajak juga dipengaruhi beberapa faktor lainya salah satunya adalah pemahaman yang kurang tentang peraturan perpajakan yang mengakibatkan kurangnya kesadaran masyarakat dalam membayar pajak. Penelitian oleh Adiputra (2014) tentang Pengaruh Tingkat Pemahaman Peraturan Pajak Wajib Pajak dan Kualitas Pelayanan Fiskus terhadap Tingkat Kepatuhan Wajib Pajak PPh Pasal 25 Badan menunjukan bahwa tingkat pemahaman peraturan pajak berpengaruh signifikan terhadap tingkat kepatuhan wajib pajak. Karena semakin tinggi tingkat pemahaman peraturan pajakwajib pajak maka tingkat kepatuhan wajib pajak dalam memenuhi kewajiban perpajakan juga akan semakin tinggi.

Selain kualitas pelayanan dan pemahaman, sanksi perpajakan juga diperlukan untuk memberikan pelajaran bagi pelanggar pajak. Wajib pajak akan memenuhi kewajiban perpajakan bila memandang bahwa sanksi perpajakan akan lebih banyak merugikannya (Djatmiko, 2009). Ali et al. (2001) dalam penelitiannya juga menyatakan bahwa auditdansanksimerupakan kebijakanyang efektifuntuk mencegah ketidakpatuhan. Mencegah ketidakpatuhan serta untuk mendorong wajib pajak untuk memenuhi kewajiban perpajakannya maka haruslah diberlakukan sanksi yang tegas dalam rangka untuk memajukan keadilan dan efektivitas sistem pajak (Webley et al., 1991). Hasil penelitian yang dilakukan oleh Purnomo (Supadmi, 2009) menemukan bahwa persepsi wajib pajak tentang sanksi perpajakan memiliki pengaruh positif terhadap kepatuhan wajib pajak. Hasilpenelitian Yadnyana dalam (Muliari dan Setiawan, 2011) menemukan bahwa sanksi perpajakan memiliki pengaruh positifpada kepatuhan wajib pajak.

Tujuan penelitian ini adalah untuk memeroleh bukti empirispengaruh kualitas pelayanan pada kepatuhan wajib pajak orang pribadi di KPP Pratama Badung Utara. Memperoleh bukti empiris pengaruh pemahaman peraturan perpajakan pada kepatuhan wajib pajak orang pribadi di KPP Pratama Badung Utara. Memperoleh bukti empiris pengaruh sanksi perpajakan pada kepatuhan wajib pajak orang pribadi di KPP Pratama Badung Utara.

Teori atribusi mencoba menemukan apa yang menyebabkan apa, atau apa yang memotivasi orang untuk melakukan apapun (Kelley, 1973). Teori atribusi menyatakan bahwa bila individu-individu mengamati perilaku seseorang, mereka mencoba untuk menentukan apakah itu ditimbulkan secara internal atau eksternal (Robbins, 1996). Fritz Heider (1958) mengemukakan bahwa pada dasarnya teori atribusi adalah proses pembentukan kesan, artinya bahwa terori atribusi merupakan proses dimana seseorang menarik kesimpulan tentang faktor-faktor yang mempengaruhi perilaku orang lain

Teori atribusi sangat relevan untuk menerangkan maksud dari pernyataan tersebut. Pada dasarnya, Perilaku yang disebabkan secara internal adalah perilaku yang diyakini berada di bawah kendali pribadi individu itu sendiri, sedangkan perilaku yang disebabkan secara eksternal adalah perilaku yang dipengaruhi dari luar, artinya individu akan terpaksa berperilaku karena situasi. Teori kepatuhan dapat mendorong seseorang untuk lebih mematuhi peraturan yang berlaku, sama halnya dengan perusahaan yang berusaha untuk menyampaikan laporan keuangan tepat waktu, juga akan bermanfaat bagipara pengguna laporan keuangan (Sulistyo, 2010). Kepatuhan merupakan suatu 
bentuk prilaku manusia yang berasal dari dorongan yang ada dalam diri manusia, sedangkan dorongan merupakan usaha untuk memenuhi kebutuhan yang ada dalam diri manusia (Heri P, 2002).

Pengertian pajak menurut Undang-Undang No.28 Tentang KUP Tahun 2007 Pasal 1 ayat (1) menyatakan bahwa "Pajak adalah kontribusi wajib kepada negara yang terutang oleh orang pribadi atau badan yang bersifat memaksa berdasarkan Undang-Undang, dengan tidak mendapatkan imbalan secara langsung dan digunakan untuk keperluan negara bagi sebesar-besarnya kemakmuran rakyat." Menurut Mardiasmo (2011:1) Pajak adalah iuran rakyat kepada kas Negara berdasarkan Undng-Undang (yang dapat dipaksakan) dengan tidak mendapatkan jasa timbal (kontraprestasi) yang langsung dapat ditujukan dan yang digunakan untuk membayar pengeluaran umum.

Pajak mempunyai peranan yang sangat penting dalam kehidupan berbangsa, khususnya dalam melaksanakan pembangunan, karena pajak merupakan sumber pendapatan negara untuk membiayai seluruh pengeluaran negara termasuk pengeluaran pembangunan. Terdapat dua fungsi pajak Mardiasmo (2011:1) yaitu: fungsi anggaran (budgetair) adalah pajak sebagai sumber dana bagi pemerintah untuk membiayai pengeluaran-pengeluarannya. Fungsi mengatur (regulerend) adalah pajak sebagai alat untuk mengatur atau melaksanakan kebijaksanaan pemerintah dalam bidang sosial dan ekonomi.

Definisi atau pengertian Wajib Pajak menurut Undang-Undang Republik Indonesia Nomor 28 Tahun 2007, Wajib Pajak Orang Pribadi adalah setiap orang pribadi yang memiliki penghasilan di atas penghasilan tidak kena pajak. Berdasarkan Surat Edaran Direktorat Jendral Pajak Nomor SE-26/PJ.2/1998 ditegaskan bahwa agar tidak menimbulkan berbagai penafsiran yang dapat menyulitkan administrasi maka perlu diberikan penegasan bahwa administrasi pajak hanya mengenal istilah wajib pajak efektif dan wajib pajak non efektif.Wajib pajak di dalam proses perhitungan hingga sampai pada pelaporan pajak hak dan kewajiban sebagaimana telah diatur dalam Undang-Undang Republik Indonesia Nomor 8 Tahun 2007 tentang Ketentuan Umum dan Tata Cara Perpajakan.

SPT adalah surat yang oleh Wajib Pajak digunakan untuk melaporkan penghitungan dan atau pembayaran pajak, objek pajak dan atau bukan objek pajak dan atau harta dan kewajiban, menurut ketentuan peraturan perundangundangan perpajakan Mardiasmo (2011:31). Menurut Mardiasmo (2011:31), fungsi Surat Pemberitahuan bagi Wajib Pajak Penghasilan adalah sebagai sarana Wajib Pajak untuk melaporkan dan mempertanggungjawabkan penghitungan jumlah pajak yang sebenarnya terutang.bagi pemotong/pemungut pajak, fungsi Surat Pemberitahuan adalah sebagai sarana untuk melaporkan dan mempertanggung-jawabkan pajak yang dipotong atau dipungut dan disetorkannya.

Kualitas adalah keseluruhan ciri-ciridan karakteristik dalam suatu produk ataujasa menyangkut kemampuan untuk memenuhi kebutuhan-kebutuhan yang telah ditentukan atau yang telah bersifat laten (Sumadi, 2005). Supadmi (2009) dalam penelitiannya menyatakan bahwa pelayanan yang berkualitas merupakan pelayananyang memberikan kepuasan kepada pelanggan dan dalam batas memenuhi standar pelayanan yang bisa dipertanggungjawabkan serta dilakukan 
secara terus-menerus. Menurut Gilbert (2006) pelayanan yang berkualitas adalah pelayanan yang dapat memberikan kepuasan kepada pelanggan dan tetap dalam batas memenuhi standar pelayanan yang dapat dipertanggungjawabkan serta harus dilakukan secara terus-menerus.

Menurut gap theory yang diusulkan oleh Parasuraman et. al (1985) bahwa kualitas pelayanan merupakan perbandingan antara harapan yang diinginkan oleh pelanggan dengan penilaian mereka terhadap kinerja aktual dari suatu penyediaan layanan. Menururt Parasuraman et. al (1985), Tjiptono (2002) ada lima dimensi yang dapat digunakan untuk mengevaluasi kualitas jasa pelayanan, yaitu:bukti langsung, keandalan (reliability), daya tanggap (responsiveness), jaminan (assurance), empati (emphaty).

Bagi pemerintah, tingkat pemahaman wajib pajak mengenai perpajakan merupakan faktor potensial untuk meningkatkan kepatuhan wajib pajak. Dalam menjalankan kewajiban perpajakanya, wajib pajak haruslah mengetahui peraturan serta kewajiban yang dijalankan agar terhindar dari sanksi-sanksi yang berlaku. Dengan demikian pemahaman tentangperpajakan berupa informasi perpajakan dan peraturan pepajakan akan meningkatkan kepatuhan seseorang dalam memenuhi kewajiban perpajakannya.

Sanksi adalah tanggungan (tindakan dan hukuman) untuk memaksa orang menepati perjanjian atau menaati ketentuan perundang-undangan. Sanksi perpajakan merupakan jaminan bahwa ketentuanperaturan perundangundangan perpajakan akan dituruti atau ditaati atau dipatuhi, dengan kata lain sanksi perpajakan merupakan alat pencegah agar wajib pajak tidak melanggar norma perpajakan menurut Mardiasmo (2011:57). Wajib pajak akan memenuhi kewajiban perpajakannya bila ia memandang atau memiliki persepsi bahwa sanksi perpajakan akan lebih banyak merugikannya (Nugroho, 2006). UndangUndang Nomor 28 Tahun 2009 mengatur tentang sanksi terhadap wajib pajak yang tidak memenuhi kewajiban perpajakannya. Bunga sebesar 2 persen dikenakan berupa sanksi administratif sebulan dari pajak yang tidak atau terlambat dibayar untuk jangka waktu paling lama 24 (dua puluh empat) bulan atas pajak yang tidak atau terlambat dibayar.

Kepatuhan perpajakan merupakan ketaatan, tunduk, dan patuh serta melaksanakan ketentuan perpajakan. Kepatuhan memenuhi kewajiban perpajakan secara sukarela, dimana wajib pajak bertanggungjawab menetapkan sendiri kewajiban perpajakan dan kemudian secara akurat dan tepat waktu membayar dan melaporkan pajaknya tersebut. Ada dua macam kepatuhan pajak, yaitu kepatuhan formal dan kepatuhan material. Kepatuhan formal adalah suatu keadaan dimana wajib pajak memenuhi kewajiban secara formal sesuai dengan ketentuan dalam Undang-Undang Perpajakan. Misalnya melaporkan SPT tepat waktu. Kepatuhan material adalah suatu keadaan dimana wajib pajak secara subtantif atau hakikatnya memenuhi semua ketentuan material perpajakan yakni sesuai dengan isi dan jiwa Undang-Undang Perpajakan. Misalnya mengisi SPT dengan jujur, lengkap dan benar, serta melaporkan ke KPP tepat waktu. 


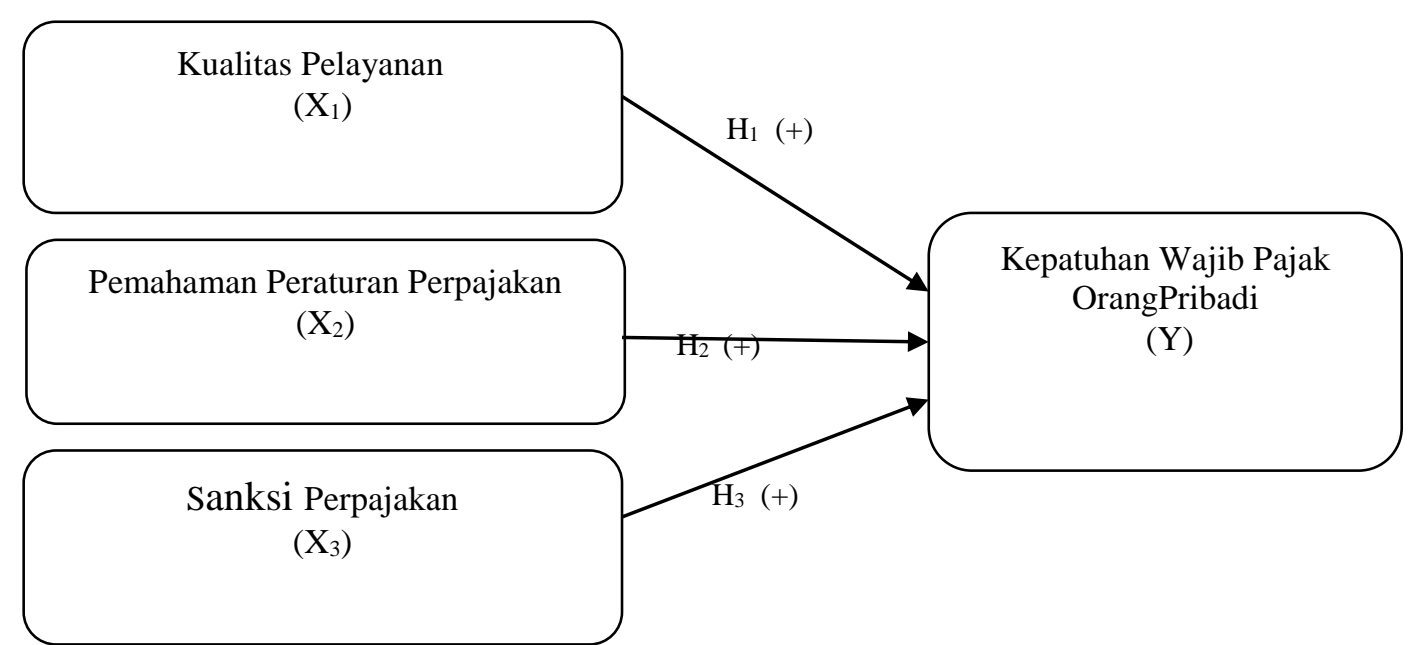

Sumber: Data Penelitian, 2019

Gambar 1. Konsep Penelitian

Kualitas pelayanan menurut teori atribusi merupakan penyebab eksternal yang mempengaruhi persepsi wajib pajak untuk membuat penilaian mengenai perilaku kepatuhan wajib pajak dalam melaksanakan kewajiban perpajakan. Berdasarkan penelitian yang dilakukan oleh Amanda (2012) menemukan bahwa, kualitaspelayanansecaraparsialberpengaruhpadakepatuhanwajibpajak dalam membayar Pajak KendaraanBermotor di Kantor Bersama SAMSAT Denpasar. Sanjaya (2014) dalam penelitiannya juga menyimpulkan kualitas pelayanan berpengaruh positif dan signifikan pada kepatuhan wajib pajak dalam membayar pajak hotel di Dinas Pendapatan Kota Denpasar.Berdasarkan uraian tersebut, dapat dikatakan bahwa pelayanan yang diberikan secara baik, dapat menimbulkan sikap puas bagi wajib pajak dan pada akhirnya akan meningkatkan kepatuhan masyarakat dalam memenuhi kewajiban perpajakannya. Berdasarkan uraian di atas, maka hipotesis penelitian yang diajukan adalah:

$\mathrm{H}_{1}$ : Kualitas pelayanan berpengaruh positif pada kepatuhan wajib pajak orang pribadi di KPP Pratama Badung Utara.

Pada penelitian yang dilakukan oleh Siregar (2012) menyatakan pemahaman perpajakan berpengaruh positif terhadap kepatuhan wajib pajak badan. Menurut Supriyatin dan Hidayati (2008)menyatakan bahwa pengetahuan atau pemahaman perpajakan memiliki pengaruh positif terhadap kepatuhan wajib pajak.Berdasarkan teori dan penelitian sebelumnya, maka hipotesis yang diajukan dalam penelitian berikut.

$\mathrm{H}_{2}$ : Pemahaman peraturan perpajakan berpengaruh positif pada kepatuhan wajib pajak orang pribadi di KPP Pratama Badung Utara.

Menurut Mardiasmo (2011:57) sanksi adalah tanggungan (tindakan dan hukuman) untuk memaksa orang menepati perjanjian atau menaati ketentuan perundang-undangan.Sanksi perpajakandibuatdengantujuan agarwajib pajak takut untuk melanggar Undang-Undang Perpajakan. Dalam teori atribusi dijelaskan bahwa perilaku seseorang dalam hal ini karakter, sikap dan lainnya dipengaruhi oleh keadaan eksternal seperti tekanan situasi atau keadaan yang memaksa seseorang untuk melakukan tindakan tertentu. Wajib pajak akan mematuhi pembayaran pajaknya bila memandang bahwa sanksi akan lebih banyak merugikannya Djatmiko (2009). 
Berdasarkan penelitian yang dilakukan oleh Arum (2012), sanksi perpajakan berpengaruh positif terhadap kepatuhan Wajib Pajak Orang Pribadi yang melakukan kegiatan usaha dan pekerjaan bebas di KPP Pratama Cilacap. Sanjaya (2014) dalam penelitiannya juga menyimpulkan bahwa, sanksi perpajakan berpengaruh positif dan signifikan pada kepatuhan wajib pajak dalam membayar pajak hotel di Dinas Pendapatan Kota Denpasar. Berdasarkan teori dan penelitian sebelumnya, maka hipotesis dalam penelitian ini adalah:

$\mathrm{H}_{3}$ : Sanksi perpajakan berpengaruh positif pada kepatuhan wajib pajak orang pribadi di KPP Pratama Badung Utara.

\section{METODE PENELITIAN}

Penelitian ini menggunakan pendekatan kuantitatif dengan tingkat eksplanasi penelitian berbentuk penelitian asosiatif. Penelitian ini untuk mengetahui hubungan variabel kualitas pelayanan, pemahaman dan sanksi perpajakan pada Kepatuhan Wajib Pajak Orang Pribadi di Kantor Pelayanan Pajak Pratama Badung Utara. Penelitian ini dilakukan di Kantor Pelayanan Pajak (KPP) Pratama Badung Utara yang beralamat di Jalan Ayani selatan, Denpasar. KPP Pratama Badung Utara dipilih sebagai lokasi penelitian karena tingkat kepatuhan wajib pajak orang pribadi masih dikatakan rendahsedangkan daerah pemungutan pajak dari KPP Pratama Badung Utara yang cukup luas. Oleh sebab itu, peneliti tertarik untuk meneliti faktor-faktor yang mempengaruhi kepatuhan Wajib Pajak Orang Pribadi di KPP Pratama Badung utara.

Obyek penelitian adalah suatu sifat dari obyek yang ditetapkan oleh peneliti untuk dipelajari dan kemudian memperoleh kesimpulan (Sugiyono, 2013:38). Obyek dalam penelitian ini adalah kepatuhan Wajib Pajak Orang Pribadi di KPP Pratama Badung Utara, khususnya mengenai pengaruh kualitas pelayanan, pemahaman, dan sanksi perpajakan.Variabel-variabel yang digunakan dalam penelitian ini yaitu: variabel terikat adalah kepatuhan Wajib Pajak Orang Pribadi (Y).Variabel independen atau variabel bebas adalah dalam penelitian ini adalah sebagai adalah kualitas pelayanan $\left(X_{1}\right)$, pemahaman perpajakan $\left(\mathrm{X}_{2}\right)$, sanksi perpajakan $\left(\mathrm{X}_{3}\right)$

Data kualitatif dalam penelitian ini adalah daftar pertanyaan-pertanyaan yang terdapat dalam kuesioner, gambaran umum, sejarah, serta struktur organisasi Kantor Pelayanan Pajak Pratama Badung Utara.Data kuantitatif dalam penelitian ini adalah data jumlah Wajib Pajak Orang Pribadi dan penerimaan pajak penghasilan wajib pajak orang pribadi di KPP Pratama Badung Utara, serta jawaban dari pertanyaan-pertanyaan kuesioner yang telah dikuantitatifkan.

Data peneilitan diperoleh dari jawaban Wajib Pajak Orang Pribadi yang berada di KPP Pratama Badung Utara, yaitu jawaban terhadap pertanyaan dalam kuesioner yang diajukan dari peneliti mengenai faktor-faktor yang mempengaruhi kepatuhan pajak. Selain Data prrmer juga terdapat bantuan data sekunder dalam penelitian ini berupa data jumlah wajib pajak orang pribadi dan data tingkat kepatuhan SPT tahunan wajib pajak orang pribadi di KPP Pratama Badung Utara.Populasi dalam penelitian ini adalah jumlah Wajib Pajak Orang Pribadi yang efektif dalam pelaporan SPT tahunan sebanyak 27.568Wajib Pajak yang terdaftar di KPP Pratama Badung Utara tahun 2017. 
Sampel adalah bagian dari jumlah dan karakteristik yang dimiliki oleh populasi tersebut (Sugiyono, 2013:118). Adapun yang menjadi sampel dalam penelitian ini adalah beberapa Wajib Pajak Orang Pribadi yang aktif dan terdaftar di KPP Pratama Badung Utara. Jumlah sampel yang digunakan dalam penelitian ini adalah sejumlah 100 Wajib Pajak Orang Pribadi yang masih aktif. Seratus wajib pajak orang pribadi yang digunakan sebagai sampel diperoleh berdasarkan perhitungan penentuan sampel dengan menggunakan rumus Slovin (Slovin, 2004:78), yaitu :

$$
\begin{aligned}
& \mathrm{n}=\frac{N}{\left(1+N e^{2}\right)} \\
& \mathrm{n}=\text { Jumlah anggota sampel } \\
& \mathrm{N} \quad=\text { Jumlah anggota populasi } \\
& \text { e } \quad=\text { Nilai kritis (batas ketelitian } 0,1 \text { ) }
\end{aligned}
$$

Perhitungan sampel :

$$
\begin{array}{ll}
\mathrm{n} & =\frac{27568}{\left(1+27568(0,1)^{2}\right)} \\
\mathrm{n} & =99,9 \\
\mathrm{n} & =100(\text { dibulatkan })
\end{array}
$$

Ukuran populasi $(\mathrm{N})$ sebesar 27.568 dengan persentase kelonggaran ketidaktelitian karena kesalahan pengambilan sampel yang ditolerir atau diinginkan (e) adalah 0,1. Melalui perhitungan menggunakan rumus Slovin, jumlah sampel yang akan digunakan dalam penelitian ini adalah sebanyak 100 sampel Wajib Pajak Orang Pribadi yang aktif di KPP Pratama Badung Utara.

Metode pengumpulan menggunakan kuesioner ini merupakan teknik pengumpulan data yang dilakukan dengan cara memberi seperangkat pertanyaan atau pertanyaan tertulis kepada responden untuk dijawab. Pemberian kuesioner dapat dilakukan dengan mendatangi dan memberikan kuesioner secara langsung kepada responden. Jawaban-jawaban responden diberi nilai/skor menggunakan skala Likert.

Observasi nonpartisipan yaitu teknik pengumpulan data dimana peneliti tidak terlibat dan hanya sebagai pengamat independen (Sugiyono, 2013:140). Peneliti mengamati, mengutip, mencatat, serta mengumpulkan data dari dokumen-dokumen perusahaan berupa sejarah berdirinya, struktur organisasi, dan uraian tugas masing-masing bagian pada KPP Pratama Badung Utara.

Analisis model linear berganda dilakukan untuk mengetahui pengaruh antar variabel terikat dan variabel bebas.Analisis dilakukan dengan bantuan program SPSS (Statistic Package of Social Science). Model regresi linear berganda dalam penelitian ini ditunjukan dengan persamaan berikut.

$Y=\alpha+\beta_{1} X_{1}+\beta_{2} X_{2}+\beta_{3} X_{3}+e$

Keterangan:

$$
\begin{aligned}
& Y: \text { Kepatuhan Wajib Pajak Orang Pribadi } \\
& a: \text { Konstanta } \\
& X_{1}: \text { Kualitas Pelayanan } \\
& X_{2}: \text { Pemahaman Perpajakan } \\
& X_{3}: \text { Sanksi Perpajakan } \\
& \beta_{1}: \text { Koefisien regresi variabel } X_{1}
\end{aligned}
$$


$\beta_{2}:$ Koefisien regresi variabel $X_{2}$

$\beta_{3}$ : Koefisien regresi variabel $X_{3}$

$\varepsilon$ : Error

Hasil analisis yang dilakukan diatas dapat diamati mengenai koefisien determinasi $\left(R^{2}\right)$, uji kelayakan model (uji F) serta uji hipotesis (uji $t$ ).

\section{HASIL DAN PEMBAHASAN}

Data penelitian diperoleh dari hasil kuesioner yang telah disebarkan kepada responden penelitian yang berjumlah 100 orang. Karakteristik responden yang diteliti meliputi jenis usaha dan sumber pengetahuan perpajakan. Ringkasan mengenai karakteristik responden dapat dilihat pada Tabel 3. sebagai berikut:

Tabel 3. Karakteristik Responden

\begin{tabular}{llcc}
\hline Variabel & \multicolumn{1}{c}{ Keterangan } & $\begin{array}{c}\text { Jumlah } \\
\text { Responden }\end{array}$ & $\begin{array}{c}\text { Presentase } \\
(\%)\end{array}$ \\
\hline Jenis Pekerjaan & PNS & 38 & 38,8 \\
& Swasta & 32 & 30,6 \\
& Lainnya & 30 & 30,6 \\
& Jumlah & 100 & 100 \\
Pengetahuan Perpajakan & & \\
& Brevet & 14 & 12,2 \\
& Penyuluhan Pajak & 30 & 30,6 \\
& Tidak Ada & 14 & 14,3 \\
& Lain-lain & 42 & 42,9 \\
& Jumlah & 100 & 100 \\
\hline
\end{tabular}

Sumber: Data Penelitian, 2019

Karakteristik responden yang disajikan pada Tabel 3 menunjukkan bahwa, jumlah responden PNS sebesar 38,8 persen, jasa sebesar 30,6 persen, dan jenis usaha lainnya sebesar 28,6 persen. Sumber pengetahuan perPajakan berdasarkan tabel 4.1 diperoleh dari brevet sebesar 14,2 persen, penyuluhan pajak sebesar 30,6 persen, tidak memperoleh pengetahuan perpajakan sebesar 14,3 persen dan dari lain-lain sebesar 42,9 persen.

Hasil uji validitas pada Tabel 4. menunjukkan bahwa seluruh instrumen penelitian yang digunakan untuk mengukur variabel kualitas pelayanan, pemahaman peraturan perpajakan, sanksi perpajakan dan kepatuhan wajib pajak memiliki nilai koefisien korelasi dengan skor total seluruh item pernyataan lebih besar dari 0,30 dengan signifikansi kurang dari 0,05. Hal ini menunjukkan bahwa butir-butir pernyataan dalam instrument penelitian tersebut valid dan layak digunakan sebagai instrument penelitian.

Hasil uji reliabilitas yang disajikan dalam Tabel 5. menunjukkan bahwa seluruh instrumen penelitian memiliki koefisien Cronbach's Alpha lebih dari 0,60. Jadi dapat dinyatakan bahwa seluruh variabel telah memenuhi syarat reliabilitas atau kehandalan sehingga dapat digunakan untuk melakukan penelitian. 
Tabel 4. Hasil Uji Validitas

\begin{tabular}{|c|c|c|c|c|}
\hline Variabel & Indikator & Koefisien Korelasi & Sig. (2-tailed) & Keterangan \\
\hline \multirow{19}{*}{$\begin{array}{l}\text { Kualitas pelayanan } \\
\qquad\left(\mathrm{X}_{1}\right)\end{array}$} & $\mathrm{X}_{1.1 .1}$ & 0,733 & 0,000 & Valid \\
\hline & $\mathrm{X}_{1.1 .2}$ & 0,733 & 0,000 & Valid \\
\hline & $\mathrm{X}_{1.1 .3}$ & 0,667 & 0,000 & Valid \\
\hline & $\mathrm{X}_{1.1 .4}$ & 0,757 & 0,000 & Valid \\
\hline & $\mathrm{X}_{1.1 .5}$ & 0,853 & 0,000 & Valid \\
\hline & $\mathrm{X}_{1.2 .1}$ & 0,797 & 0,000 & Valid \\
\hline & $\mathrm{X}_{1.2 .2}$ & 0,795 & 0,000 & Valid \\
\hline & $\mathrm{X}_{1.2 .3}$ & 0,804 & 0,000 & Valid \\
\hline & $\mathrm{X}_{1.2 .4}$ & 0,717 & 0,000 & Valid \\
\hline & $\mathrm{X}_{1.3 .1}$ & 0,848 & 0,000 & Valid \\
\hline & $\mathrm{X}_{1.3 .2}$ & 0,846 & 0,000 & Valid \\
\hline & $\mathrm{X}_{1.3 .3}$ & 0,799 & 0,000 & Valid \\
\hline & $\mathrm{X}_{1.4 .1}$ & 0,698 & 0,000 & Valid \\
\hline & $\mathrm{X}_{1.4 .2}$ & 0,681 & 0,000 & Valid \\
\hline & $\mathrm{X}_{1.4 .3}$ & 0,677 & 0,000 & Valid \\
\hline & $\mathrm{X}_{1.4 .4}$ & 0,724 & 0,000 & Valid \\
\hline & $X_{1.5 .1}$ & 0,717 & 0,000 & Valid \\
\hline & $\mathrm{X}_{1.5 .2}$ & 0,819 & 0,000 & Valid \\
\hline & $X_{2.1}$ & 0,760 & 0,000 & Valid \\
\hline \multirow{5}{*}{$\begin{array}{l}\text { Pemahaman } \\
\text { peraturan } \\
\text { perpajakan }\left(X_{2}\right)\end{array}$} & $X_{2.2}$ & 0,784 & 0,000 & Valid \\
\hline & $\mathrm{X}_{2.3}$ & 0,716 & 0,000 & Valid \\
\hline & $\mathrm{X}_{2.4}$ & 0,752 & 0,000 & Valid \\
\hline & $\mathrm{X}_{2.5}$ & 0,815 & 0,000 & Valid \\
\hline & $X_{3.1}$ & 0,645 & 0,000 & Valid \\
\hline \multirow{5}{*}{$\begin{array}{l}\text { Sanksi perpajakan } \\
\qquad\left(\mathrm{X}_{3}\right)\end{array}$} & $X_{3.2}$ & 0,732 & 0,000 & Valid \\
\hline & $X_{3.3}$ & 0,672 & 0,000 & Valid \\
\hline & $X_{3.4}$ & 0,813 & 0,000 & Valid \\
\hline & $X_{3.5}$ & 0,467 & 0,000 & Valid \\
\hline & $X_{3.6}$ & 0,631 & 0,000 & Valid \\
\hline \multirow{4}{*}{$\begin{array}{l}\text { Kepatuhan wajib } \\
\text { pajak(Y) }\end{array}$} & $Y_{1}$ & 0,714 & 0,000 & Valid \\
\hline & $Y_{2}$ & 0,872 & 0,000 & Valid \\
\hline & $Y_{3}$ & 0,772 & 0,000 & Valid \\
\hline & $Y_{4}$ & 0,700 & 0,000 & Valid \\
\hline
\end{tabular}

Sumber: Data Penelitian, 2019

Uji normalitas bertujuan untuk mengetahui apakah residual dari model regresi yang dibuat berdistribusi normal atau tidak. Dalam penelitian ini uji normalitas dilakukan dengan menguji normalitas residual dengan menggunakan uji Kolmogorov-Smirnov. Jika probabilitas signifikansi nilai residual lebih besar dari 0,05 maka data tersebut dikatakan berdistribusi normal. 
Tabel 5. Hasil Uji Reliabilitas

\begin{tabular}{clcc}
\hline No. & \multicolumn{1}{c}{ Variabel } & Cronbach's Alpha & Keterangan \\
\hline 1 & Kualitas pelayanan $\left(\mathrm{X}_{1}\right)$ & 0,802 & Reliabel \\
2 & Pemahaman peraturan perpajakan $\left(\mathrm{X}_{2}\right)$ & 0,797 & Reliabel \\
3 & Sanksi perpajakan $\left(\mathrm{X}_{3}\right)$ & 0,763 & Reliabel \\
4 & Kepatuhan wajib pajak $(\mathrm{Y})$ & 0,804 & Reliabel \\
\hline
\end{tabular}

Sumber: Data Penelitian, 2019

Berdasarkan hasil analisis pada Tabel 6. didapat nilai signifikansi sebesar 0,956 yang lebih dari 0,05 maka dapat disimpulkan bahwa model persamaan regresi dalam penelitian ini sudah berdistribusi normal.

\section{Tabel 6. Hasil Uji Normalitas}

\begin{tabular}{lc}
\hline & Unstandardized Residual \\
\hline $\mathrm{N}$ & 100 \\
Kolmogorov-Smirnov Z & 0,511 \\
Asymp. Sig. (2-tailed) & 0,956 \\
\hline
\end{tabular}

Sumber: Data Penelitian, 2019

Berdasarkan Tabel 7 dapat dilihat bahwa nilai tolerance dan VIF dari seluruh variabel bebas yang diuji yaitu kualitas pelayanan, pemahaman peraturan perpajakan, dan sanksi perpajakan menunjukkan bahwa nilai tolerance untuk setiap variabel lebih besar dari 0,10 dan nilai VIF lebih kecil dari 10 yang berarti model persamaan regresi bebas dari multikolinearitas.

\section{Tabel 7. Hasil Uji Multikoleniaritas}

\begin{tabular}{lccc}
\hline \multicolumn{1}{c}{ Variabel } & Tolerance & VIF & Keterangan \\
\hline Kualitas pelayanan $\left(\mathrm{X}_{1}\right)$ & 0,913 & 1,095 & Bebas multikol \\
Pemahaman peraturan perpajakan $\left(\mathrm{X}_{2}\right)$ & 0,884 & 1,131 & Bebas multikol \\
Sanksi perpajakan $\left(\mathrm{X}_{3}\right)$ & 0,936 & 1,068 & Bebas multikol \\
\hline
\end{tabular}

Sumber: Data Penelitian, 2019

Pada Tabel 8. dapat dilihat bahwa nilai signifikansi dari variabel kualitas pelayanan sebesar 0,746, nilai signifikansi variabel pemahaman peraturan perpajakan sebesar 0,514, dan sanksi perpajakan sebesar 0,872. Nilai tersebut lebih besar dari 0,05 yang berarti tidak terdapat pengaruh antara variabel bebas terhadap absolute residual. Dengan demikian, model yang dibuat tidak mengandung gejala heteroskedastisitas.

\section{Tabel 8. Hasil Uji Heteroskedastisitas}

\begin{tabular}{|c|c|c|c|c|c|}
\hline \multirow[t]{2}{*}{ Model } & \multicolumn{2}{|c|}{$\begin{array}{l}\text { Unstandardized } \\
\text { Coefficients }\end{array}$} & \multirow{2}{*}{$\begin{array}{c}\begin{array}{c}\text { Standardized } \\
\text { Coefficients }\end{array} \\
\text { Beta }\end{array}$} & \multirow[b]{2}{*}{$\mathrm{t}$} & \multirow[b]{2}{*}{ Sig. } \\
\hline & B & Std. Error & & & \\
\hline 1 (Constant) & 2.165 & 1.481 & & 1.461 & .147 \\
\hline Kualitas pelayanan & -.005 & .017 & -.034 & -.324 & .746 \\
\hline $\begin{array}{l}\text { Pemahaman peraturan } \\
\text { perpajakan }\end{array}$ & -.027 & .042 & -.071 & -.655 & .514 \\
\hline Sanksi perpajakan & -.006 & .038 & -.017 & -.161 & .872 \\
\hline
\end{tabular}

Sumber: Data Penelitian, 2019

Berdasarkan hasil uji statistik deskriptif pada Tabel 9 dapat diketahui bahwa total sampel yang digunakan adalah 100 orang responden wajib pajak orang pribadi yang terdaftar di Kantor Pelayanan Pajak Pratama Badung Utara. Hasil statistik deskriptif dalam penelitian ini dapat dijelaskan bahwa variabel 
kualitas pelayanan memiliki nilai minimum sebesar 55,00 dan nilai maksimum sebesar 90,00. Variable kualitas pelayanan yang diukur dengan 5 indikator pertanyaan dengan nilai rata-rata 75,29 dengan nilai standar deviasi sebesar 4,74. Hal ini berarti nilai standar deviasi lebih rendah dibandingkan dengan nilai ratarata, yang artinya sebaran data terkait dengan kualitas pelayanan sudah merata.

Tabel 9. Hasil Statistik Deskriptif

\begin{tabular}{lrrrcr}
\hline & N & Minimum & Maximum & Mean & Std. Deviation \\
\hline Kualitas Pelayanan & 100 & 55.00 & 90.00 & 75.2900 & 4.74245 \\
Pemahaman & 100 & 16.00 & 25.00 & 21.0100 & 1.93059 \\
Sanksi & 100 & 21.00 & 30.00 & 25.9900 & 2.07678 \\
Kepatuhan & 100 & 14.00 & 20.00 & 17.8900 & 1.40630 \\
Valid N (listwise) & 100 & & & & \\
\hline
\end{tabular}

Sumber: Data Penelitian, 2019

Variabel pemahaman perpajakan memiliki nilai minimum sebesar 16,00 dan nilai maksimum sebesar 25,00. Variable kualitas pelayanan yang diukur dengan 5 item pertanyaan dengan bantuan skala likert 5 poin memiliki nilai ratarata 21,01 dengan nilai standar deviasi sebesar 1,93. Hal ini berarti nilai standar deviasi lebih rendah dibandingkan dengan nilai rata-rata, yang artinya sebaran data terkait dengan kualitas pelayanan sudah merata.

Variabel sanksi perpajakan memiliki nilai minimum sebesar 21,00 dan nilai maksimum sebesar 30,00. VariabEL kualitas pelayanan yang diukur dengan 7 item pertanyaan dengan nilai rata-rata 25,99 dengan nilai standar deviasi sebesar 2,07. Hal ini berarti nilai standar deviasi lebih rendah dibandingkan dengan nilai rata-rata, yang artinya sebaran data terkait dengan kualitas pelayanan sudah merata.

Variabel kepatuhan wajib pajak memiliki nilai minimum sebesar 14,00 dan nilai maksimum sebesar 20,00. Variable kualitas pelayanan yang diukur dengan 4 item pertanyaan dengan nilai rata-rata 17,89 dengan nilai standar deviasi sebesar 1,40. Hal ini berarti nilai standar deviasi lebih rendah dibandingkan dengan nilai rata-rata, yang artinya sebaran data terkait dengan kualitas pelayanan sudah merata.

Tabel 10. Hasil Analisis Regresi Linier Berganda

\begin{tabular}{|c|c|c|c|c|c|}
\hline \multirow[t]{2}{*}{ Variabel } & \multicolumn{2}{|c|}{$\begin{array}{l}\text { Unstandardized } \\
\text { Coefficients }\end{array}$} & \multirow{2}{*}{$\begin{array}{c}\begin{array}{c}\text { Standardized } \\
\text { Coefficients }\end{array} \\
\text { Beta }\end{array}$} & \multirow[t]{2}{*}{ t hitung } & \multirow[t]{2}{*}{$\begin{array}{l}\text { Sig. } \\
\text { uji t }\end{array}$} \\
\hline & B & Std. Error & & & \\
\hline (Constant) & 6,481 & 2,523 & & 2,569 & 012 \\
\hline Kualitas pelayanan & ,062 & ,029 & ,210 & 2,182 & ,032 \\
\hline $\begin{array}{l}\text { Pemahaman peraturan } \\
\text { perpajakan }\end{array}$ & 154 & ,071 & ,211 & 2,159 & ,033 \\
\hline Sanksi perpajakan & 134 & 064 & 198 & 2,075 & ,041 \\
\hline R Square & 0,185 & & & & \\
\hline Adjusted R Square & 0,160 & & & & \\
\hline F Statistik & 7,282 & & & & \\
\hline Signifikansi Uji F & 0,000 & & & & \\
\hline
\end{tabular}


Berdasarkan hasil analisis regresi linier berganda seperti yang disajikan pada Tabel 10, maka dapat dibuat persamaan regresi sebagai berikut:

$$
Y=7,282+0,062 X_{1}+0,154 X_{2}+0,134 X_{3}
$$

Tabel 10. menunjukkan koefisien regresi pada masing-masing variabel bebas yang diuji memiliki arah koefisien yang positif dan memiliki nilai signifikansi kurang dari 0,05. Hal ini menunjukkan bahwa seluruh variabel bebas dalam penelitian ini memiliki pengaruh yang positif dan signifikan pada variabel kepatuhan wajib pajak.

Hasil uji koefisien determinasi pada Tabel 4.8 menunjukkan nilai $\mathrm{R}$ Square sebesar 0,185 mempunyai arti bahwa sebesar 18,5\% variasi kepatuhan wajib pajak pada KPP Pratama Badung Utara dipengaruhi oleh variasi kualitas pelayanan, pemahaman peraturan perpajakan, dan sanksi perpajakan, sedangkan sisanya sebesar $81,5 \%$ dijelaskan oleh faktor lain yang tidak dimasukkan ke dalam model.

Hasil pengolahan analisis regresi berganda dengan menggunakan program SPSS diperoleh nilai $F_{\text {hitung }}$ sebesar 7,282 dengan signifkansi sebesar 0,000. Oleh karena nilai $F_{\text {hitung }}$ sebesar 7,282 dengan nilai signifikansi $0,000<0,05$, maka dapat disimpulkan bahwa pada kelompok yang diuji memiliki perbedaan yang nyata (signifikan).Hasil ini mempunyai arti bahwa secara simultan kualitas pelayanan, pemahaman peraturan perpajakan, dan sanksi perpajakan berpengaruh signifikan terhadap kepatuhan wajib pajak pada KPP Pratama Badung Utara.

Pengaruh secara parsial pada variabel kualitas pelayanan, pemahaman peraturan perpajakan, dan sanksi perpajakan terhadap kepatuhan wajib pajak diuji dengan menggunakan uji regresi linier berganda yang ditinjau berdasarkan nilai $\mathrm{t}$ hitung pada tabel coeffisient. Kriteria pengujian untuk menjelaskan interpretasi pengaruh antar masing-masing variabel yakni apabila nilai signifikansi $<0,05$ maka $\mathrm{H}_{0}$ ditolak dan $\mathrm{H}_{1}$ diterima. Sebaliknya, jika nilai signifikansi $>0,05$ maka $\mathrm{H}_{0}$ diterima dan $\mathrm{H}_{1}$ ditolak.

Tabel 11. Hasil Uji Hipotesis (Uji t)

\begin{tabular}{clccc}
\hline No & Variabel & T hitung & Sig. & Simpulan \\
\hline 1 & Kualitas pelayanan $\left(\mathrm{X}_{1}\right)$ & 2.182 & .032 & $\mathrm{H}_{1}$ diterima \\
2 & Pemahaman Peraturan & 2.159 & .033 & $\mathrm{H}_{2}$ diterima \\
& Perpajakan $\left(\mathrm{X}_{2}\right)$ & & & \\
3 & Sanksi Perpajakan $\left(\mathrm{X}_{3}\right)$ & 2.075 & .041 & $\mathrm{H}_{3}$ diterima \\
\hline
\end{tabular}

Sumber: Data Penelitian, 2019

Berdasarkan Tabel 11 dapat dilihat bahwa terdapat pengaruh yang signifikan antara variabel kualitas pelayanan, pemahaman peraturan perpajakan, dan sanksi perpajakan terhadap kepatuhan wajib pajak orang pribadi di KPP Pratama Badung Utara. Hasil uji t untuk $\mathrm{H}_{1}$ diperoleh angka t-hitung sebesar 2.182 dengan nilai signifikasi sebesar 0,032 dan nilai koefisien regresi positif sebesar 0,062. Nilai Signifikansi 0,032 < 0,05 mengindikasikan bahwa $\mathrm{H}_{1}$ diterima. Hasil ini mempunyai arti bahwa kualitas pelayanan berpengaruh positif pada kepatuhan wajib pajak di KPP Pratama Badung Utara.

Hasil uji $\mathrm{t}$ untuk $\mathrm{H}_{2}$ diperoleh angka thitung sebesar 2.159 dengan nilai signifikansi sebesar 0,033 dan nilai koefisien regresi yang positif sebesar 0,154. Nilai Signifikansi 0,033 <0,050, maka mengindikasikan bahwa $\mathrm{H}_{2}$ diterima. Hasil 
ini mempunyai arti bahwa Pemahaman peraturan perpajakan berpengaruh positif pada kepatuhan wajib pajak di KPP Pratama Badung Utara.

Hasil uji $\mathrm{t}$ untuk $\mathrm{H}_{3}$ diperoleh angka t-hitung sebesar 2.075 dengannilai signifikansi sebesar 0,041 dan nilai koefisien regresi positif sebesar 0,134. Nilai signifikansi 0,041 < 0,050 mengindikasikan bahwa $\mathrm{H}_{3}$ diterima. Hasil ini mempunyai arti bahwa sanksi perpajakan berpengaruh positif pada kepatuhan wajib pajak di KPP Pratama Badung Utara.

Variabel kualitas pelayanan $\left(\mathrm{X}_{1}\right)$ dengan nilai signifikansi 0,032 $<0,05$ dan mempunyai nilai $\mathrm{t}$ hitung adalah 2.182> nilai $\mathrm{t}$ tabel 0,062, maka dapat disimpulkan bahwa kualitas pelayanan berpengaruh positif pada kepatuhan wajib pajak orang pribadi di KPP Pratama Badung Utara. Hasil penelitian ini sejalan dengan penelitian yang dilakukan olehIndra (2015) yang menyatakan kualitas pelayanan berpengaruh positif dan signifikan pada kepatuhan wajib pajak badan di KPP Pratama Gianyar. Sanjaya (2014) dalam penelitiannya juga menyimpulkan kualitas pelayanan berpengaruh positif dan signifikan pada kepatuhan wajib pajak dalam membayar pajak hotel di Dinas Pendapatan Kota Denpasar.

Hasil penelitian ini mendukung teori atribusi yang dimana kualitas pelayanan yang baik diberikan oleh fiskus secara langsung akan berdampak pada meningkatnya kepatuhan wajib pajak dalam melaksanakan kewajiban perpajakanya, jadi memberikan pelayanan yang berkualitas pada wajib pajak akan membuat wajib pajak lebih meningkatkan kepatuhan wajib pajak dalam memenuhi kewajiban perpajakannya. Penelitian ini juga mendukung teori kepatuhan yang dimana kualitas pelayanan fiskus akan mempengaruhi tingkat kepatuhan wajib pajak dalam memenuhi kewajiban perpajakanya, jadi kualitas pelayanan yang baik akan membuat wajib pajak nyaman dan meningkatkan kepatuhannya dalam memenuhi kewajiban perpajakanya.

Variabel kualitas pelayanan $\left(X_{2}\right)$ dengan Nilai Signifikansi 0,033 $<0,050$ dan mempunyai nilai $t$ hitung adalah 2.159> nilai $t$ tabel 0,154 , maka dapat disimpulkan bahwa pemahaman peraturan perpajakan berpengaruh positif pada kepatuhan wajib pajak orang pribadi di KPP Pratama Badung Utara.Hasil penelitian ini sejalan dengan penelitian Candra (2017) yang menyatakan bahwa pengetahuan dan pemahaman tentang peraturan pajak berpengaruh positif terhadap kemauan membayar pajak WPOP di KPP Pratama Denpasar Timur. Penelitian ini juga sejalan dengan penelitian yang dilakukan oleh Faris (2018) yang menyatakan bahwa pemahaman prosedur perpajakan berpengaruh positif terhadap kepatuhan wajib pajak orang pribadi di KPP Pratama Tabanan.

Hasil penelitian ini mendukung teori atribusi yang dimana semakin tinggi pemahaman peraturan perpajakan yang diketahui oleh wajib pajak maka semakin tinggi pula kesadaran yang dimiliki wajib pajak sehingga dapat meningkatkan kepatuhan wajib pajak dalam memenuhi kewajiban perpajakannya, sebaliknya jika semakin rendah pemahaman peraturan perpajakan yang diperoleh wajib pajak maka semakin rendah pula kesadaran wajib pajak sehingga dapat menurunkan kepatuhan wajib pajak dalam memenuhi kewajiban perpajakannya. Penelitian ini juga mendukung teori kepatuhan yang dimana semakin tinggi pemahaman peraturan perpajakanya 
maka semakin tinggi pula kesadaran wajib pajak dalam memenuhi kewajiban perpajakanya. Variabel sanksi perpajakan $\left(X_{3}\right)$ dengan Nilai Signifikansi 0,041 < 0,050dan mempunyai nilai t hitung adalah $2.075>$ nilai $t$ tabel 0,134, maka dapat disimpulkan bahwa sanksi perpajakan berpengaruh positif pada kepatuhan wajib pajak orang pribadi di KPP Pratama Badung Utara.

Hasil penelitian ini sejalan dengan penelitianyang dilakukan oleh Indra (2015) yang menyatakan bahwa sanksi perpajakan berpengaruh positif dan signifikan pada kepatuhan wajib pajak badan di KPP Pratama Gianyar. Hasil penelitian ini juga didukung penelitian yang dilakukan oleh Sanjaya (2014) dimana sanksi perpajakan memiliki pengaruh positif dan signifikan pada kepatuhan wajib pajak karena apabila sanksi perpajakan ditaati, maka akan cenderung meningkatkan kepatuhan wajib pajak dalam membayar kewajiban perpajakannya.

Hasil penelitian ini mendukung teori atribusi yang dimana Sanksi perpajakan merupakan jaminan bahwa ketentuan peraturan undang-undang perpajakan akan dituruti/ditaati/dipatuhi, dengan kata lain sanksi perpajakan merupakan alat pencegah agar wajib pajak tidak melanggar norma perpajakan (Mardiasmo, 2011:47). Wajib pajak akan memenuhi kewajiban perpajakannya bila memandang bahwa sanksi perpajakan akan lebih banyak merugikannya sehingga wajib pajak tersebut lebih memilih untuk mematuhi kewajiban perpajakan yang harus dibayarnya. Penelitian ini juga mendukung teori kepatuhan karena apabila wajib pajak memandang bahwa sanksi perpajakan akan lebih banyak merugikannya maka wajib pajak tersebut akan memilih untuk meningkatkan kepatuhan kewajiban pajak dalam membayar atau melaporkan kewajiban perpajakannya.

\section{SIMPULAN}

Berdasarkan hasil analisis data dan pembahasan maka dapat ditarik kesimpulan sebagai berikut: kualitas pelayanan berpengaruh positif pada kepatuhan wajib pajak orang pribadi di KPP Pratama Badung Utara.Pemahaman peraturan perpajakan berpengaruh positif pada kepatuhan wajib pajak orang pribadi di KPP Pratama Badung Utara.Sanksi perpajakan berpengaruh positif pada kepatuhan wajib pajak orang pribadi di KPP Pratama Badung Utara

Berdasarkan hasil penelitian dan simpulan maka saran yang dapat disampaikan adalah Kualitas pelayanan, pemahaman peraturan dan sanksi perpajakan mempunyai pengaruh positif terhadap kepatuhan wajib pajak orang pribadi di KPP Pratama Badung Utara. Berdasarkan hasil penelitian tersebut maka KPP Pratama Badung Utara hendaknya harus dapat menjaga dan meningkatkan kualitas pelayanan yang diberikan kepada wajib pajak agar wajib pajak dengan nyaman dalam memenuhi kewajiban perpajakanya. Sosialisasi perpajakan terhadap wajib pajak harus juga lebih sering di laksanakan agar wajib pajak lebih memahami prosedur dan peraturan perpajakan. Selain itu untukmeningkatkan kepatuhan wajib pajak, efektifitas sanksi perpajakanpada wajib pajak yang melanggar peraturan perundang-udangan khususnya pada wajib pajak orang pribadi dengan cara meningkatkan jumlah denda bagi para penunggak pajak, sehingga dapat memberikan efek jera pagi pelanggarnya. 
Penelitian ini terbatas hanya meneliti kepatuhan wajib pajak orang pribadi di KPP Pratama Badung Utara. Peneliti selanjutnya disarankan dapat menambah jumlah sampel dengan cara memperluas wilayah penelitan hingga keluar daerah atau bahkan dapat dilakukan penelitian pada dinas pendapatan di seluruh Indonesia sehingga hasil penelitian dapat digeneralisasikan.

\section{REFERENSI}

Alifa, Nur Rohmawati. (2011). Pengaruh Kesadaran Wajib Pajak, Penyuluhan Perpajakan, Kualitas Pelayanan, dan Persepsi Tentang Sanksi Perpajakan pada Kepatuhan Wajib Pajak Orang Pribadi di Kantor Pelayanan Pajak Pratama Denpasar Barat. E-jurnal Akuntansi Fakultas Ekonomi Universitas Udayana, Denpasar.

Andini, Permata S \& Made Gede Wirakusuma. (2018). Persepsi Tax Amnesty Sebagai Pemoderasi Pengaruh Kesadaran Wajib Pajak dan Sanksi Perpajakan Pada Kepatuhan WPOP. E-Jurnal Akuntansi Universitas Udayana. 22.1, 464-491. https:/ / doi.org/10.2484/EJA/2018.v22.i01.p18

Amanda, R. Siswanto Putri. (2012). Pengaruh Kesadaran Wajib Pajak, Kewajiban Moral, Kualitas Pelayanan, dan Sanksi Perpajakan Terhadap Kepatuhan Wajib Pajak dalam Membayar Pajak Kendaraan Bermotor (PKB) pada Kantor Bersama Samsat Kota Denpasar. Jurnal Akuntansi Universitas Udayana, Denpasar.

Arum, Harjianti Puspa. (2012). Pengaruh Kesadaran Wajib Pajak, Pelayanan Fiskus, dan Sanksi Pajak Terhadap Kepatuhan Wajib Pajak Orang Pribadi yang Melakukan Kegiatan Usaha danPekerjaanBebas (Studi di Wilayah KPP Pratama Cilacap). Jurnal Akuntansi Fakultas Ekonomidan Bisnis Universitas Diponogoro, Semarang.

Gilbert, Ronald G. (2006). A Cross-Industry Comparisson of Customer Satisfaction. Journal of Services Marketing. Collage of Bussines Administration.Florida International University, 20(5), h: 298-308.

Hardiningsih, Pancawati\&NilaYulianawati. (2011). Faktor-Faktor yang Mempengaruhi Kemauan Membayar Pajak. Dinamika Keuangandan Perbankan, 3(1), h: 126-142.

Hoffmann, E., Gagl, K., Kirchler, E., \& Stark, J. (2014). Enhancing Tax Compliance Trhought Coercive And Legitimate Power Of Tax Authorities By Concurrently Diminishing Of Facilitating Trust In Tax Authorities. Law And Policy, 36(3), 290-313

Indra, Pradnya Paramarta I Putu\& Ni KetutRasmini. (2016). Pengaruh Kualitas Pelayanan, Pengetahuan dan Sanksi Perpajakan Terhadap Kepatuhan Wajib Pajak Badan. E-Jurnal Akuntansi Universitas Udayana.

Inten, A. A Yulitasari \& Hermanus Bambang Suprasto. (2017). Pengaruh Tanggung Jawab Moral, Sanksi Perpajakan Dan Penerapan SistemE-Filing Pada Kepatuhan Pelaporan Wajib Pajak. E-Juirnal Akuntansi Universitas Udayana. 20.2 1360-1389

James, Simon \& Clinton Alley. (2004). Tax Compliance, Self Assessment and Tax Administration. Journal of Finance and Management in Public Services, 2(2), pp: $27-42$. 
Josephine, Nidya Prajogo. (2013). Pengaruh Tingkat Pemahaman Peraturan Pajak Wajib Pajak, Kualitas Pelayanan Petugas Pajak, dan Persepsi Atas Sanksi Perpajakan Terhadap Kepatuhan Wajib Pajak UMKM di Wilayah Sidoarjo. Jurnal Akuntansi Universitas Kristen Petra.

Mardiasmo. (2011). Perpajakan. Edisi Revisi. Yogyakarta: Andi.

Muliari, Ni Ketut dan Putu Ery Setiawan. (2011). Pengaruh Persepsi Tentang Sanksi Perpajakan dan Kesadaran Wajib Pajak Pada Kepatuhan Pelaporan Wajib Pajak Orang Pribadi di KPP Denpasar Timur. Jurnal Akuntasi Bisnis, Vol.6.

Noviantari, P. and Setiawan, P. E. (2018) 'Pengaruh Persepsi Kualitas Pelayanan, Pemahaman, Persepsi Sanksi Perpajakan, dan Lingkungan Terhadap Kepatuhan wajib Pajak', E-Jurnal Akuntansi Universitas Udayana, 22, pp. 1711-1740.

Palda,Filip dan Jan Hanousek.(2002).Quality of Government Services and the Civic Duty to Pay Taxesin the Czech and Slovak Republics, and other Transition Countries.

Parasuraman, Zeithaml, Berry. (1985). A Conceptual Model of Service Quality Its Implication Future Research. Journal of Marketing, 49: h: 41-50.

Permatasari, Aprilia. (2012). Pengaruh Kesadaran Wajib Pajak dan Sanksi Perpajakan pada Kepatuhan Wajib Pajak dalam Membayar Pajak Bumi dan Bangunan (PBB) di Kantor Pelayanan Pajak (KPP) Pratama Denpasar Timur.

Pratiwi, I GustiAyu Made Agung Mas Andriani. (2013). Pengaruh Kesadaran Wajib Pajak, Kualitas Pelayanan, Kondisi Keuangan Perusahaan, dan Persepsi Tentang Sanksi Perpajakan pada KepatuhanWajib Pajak Reklame di Dinas Pendapatan Kota Denpasar. E-jurnal Akuntansi Universitas Udayana, Denpasar.

Rizal, Palil Mohd., \& Ahmad Fariq Mustaspha. (2011). Factors Affecting Tax Compliance Behaviour In Self Assessmentsytem. 5(33) 12864-12872. School Of Accounting, Faculty Of Economics And Business University Kebangsaan Malaysia.

Sanjaya, I PutuAdi Putra. (2013). Pengaruh Kualitas Pelayanan, Kewajiban Moral dan Sanksi Perpajakan pada KepatuhanWajib Pajak dalam Membayar Pajak Hotel di Dinas Pendapatan Kota Denpasar. Jurnal Akuntansi Fakultas Ekonomi UniversitasUdayana, Denpasar.

Simanjuntak, Timbul Hamonangan. (2009). Kepatuhan Pajak (Tax Complience) dan Bagi Hasil Pajak dalam Perekonomian di Jawa Timur. JESP, 1(2).

Sri Handayani, Ni Made, (2013), Pengaruh Kesadaran Wajib Pajak, Pengetahuan Perpajakan, dan Biaya Kepatuhan Terhadap Kepatuhan Pelaporan Wajib Pajak Orang Pribadi di Kantor Pelayanan Pajak Pratama Denpasar Timur. Jurnal Akuntansi Universitas Warmadewa, Denpasar.

Sri Rahayu Trisna Dewi,Ni Nym. (2011). Pengaruh Kualitas Pelayanandan Sanksi Perpajakan serta Kesadaran Wajib Pajak terhadap Tingkat Kepatuhan Wajib Pajak dalam Membayar Pajak Kendaraan Bermotor di Kantor Bersama Samsat Denpasar. Jurnal Akuntansi Fakultas Ekonomi Universitas Udayana. 
Suardikha, I Made Sadha. (2009). Pengaruh Sistem Perpajakan yang Kondusif Terhadap Dunia Usaha. Audi Jurnal Akuntansi Universitas Udayana. 2 (2): h:68,

Sugiyono. (2013). Metode Penelitian Bisnis. Bandung: Alfabeta.

Sumadi. (2005). Pengaruh Kualitas Pelayanan Terhadap Kepuasan Wajib Pajak (Studipada Obyek Pajak Penghasilan di KPP Yogyakarta Satu. Jurnal Bisnis dan Manajemen Fakultas EkonomiUniversitas Islam Indonesia.

Sumantara, I Wayan. (2012). Analisis Tingak Kepatuhan Wajib Pajak Hotel dan Restoran Berdsarkan Peraturan Daerah Nomor 20 dan 21 Tahun 2001 di Kabupaten Badung. Jurnal Akuntansi Fakultas Ekonomi Universitas Udayana Supadmi, Ni Luh. (2009). Meningkatkan Kepatuhan Wajib Pajak Melalui Kualitas Pelayanan. Audi Jurnal Akuntansi dan Bisnis, 4 (2): h:214-219, Denpasar: Fakultas Ekonomi Universitas Udayana.

Susilawati, Evi Ketut. (2013). Pengaruh KesadaranWajib Pajak, Pengetahuan Pajak, Sanksi Perpajakan dan Akuntabilitas Pelayanan Publik pada KepatuhanWajib Pajak Kendaraan Bermotor. E-Jurnal Akuntansi Universitas Udayana, 4(2): h: 345-357.

Trisna Dewi, Ni LuhPutu. (2010). Pengaruh Kewajiban Moral, KualitasPelayanan, dan Biaya Kepatuhan Pajak pada Kepatuhan Pelaporan Wajib Pajak Orang Pribadi di Kantor PelayananPajakPratama Denpasar Timur. E-Jurnal Akuntansi Universitas Udayana, Denpasar.

Undang-Undang Republik Indonesia Nomor 28 Tahun 2007 Tentang Ketentuan Umum dan Tata Cara Perpajakan. Jakarta: Penerbit Buku Berita Pajak

Utami, Sri Rizki. (2012). Pengaruh Faktor-Faktor EksternalTerhadap Tingkat Kepatuhan Wajib Pajak di Lingkungan Kantor Pelayanan Pajak Pratama Serang.

Webley, P., H. Robben.,H. ElffersdanD. Hessing.(1991).TaxEvasion:An Experimental Approach. Cambrdige, United Kingdom:Cambridge UniversityPress

Yudi Arista, Made. (2011). PengaruhKualitasPelayananDan Kewajiban Moral Terhadap KepatuhanWajibPajak dalam Membayar PajakKendaraan Bermotor Pada Kantor BersamaSamsat Denpasar. E-Jurnal Akuntansi Universitas Udayana.

Tsikas, S. A. (2017). Enforce Tax Compliance, But Cautiously: The Role Of Trust In Authorities And Power Of Authorities. Hannover Economic Papers, 132 